\title{
Tsunami hazard in the Black Sea and the Azov Sea: a new tsunami catalogue
}

\author{
G. A. Papadopoulos ${ }^{1}$, G. Diakogianni ${ }^{1}$, A. Fokaefs ${ }^{1}$, and B. Ranguelov ${ }^{2}$ \\ ${ }^{1}$ Institute of Geodynamics, National Observatory of Athens, 11810 Athens, Greece \\ ${ }^{2}$ Geophysical Institute, Bulgarian Academy of Sciences, Sofia, Bulgaria
}

Received: 1 September 2010 - Revised: 1 December 2010 - Accepted: 1 December 2010 - Published: 25 March 2011

\begin{abstract}
Data on tsunamis occurring in the Black Sea and the Azov Sea from antiquity up to the present were updated, critically evaluated and compiled in the standard format developed since the 90's for the New European Tsunami Catalogue. Twenty nine events were examined but three of them, supposedly occurring in $557 \mathrm{AD}, 815 \mathrm{AD}$ and 1341 or 1343 , were very likely falsely reported. Most of the remaining 26 events were generated in Crimea, offshore Bulgaria as well as offshore North Anatolia. For each of the 26 events examined, 22 events were classified as reliable ones receiving a score of 3 or 4 on a 4 -grade reliability scale. Most of them were caused by earthquakes, such as the key event 544/545 of offshore Varna, but a few others were attributed either to aseismic earth slumps or to unknown causes. The tsunami intensity was estimated using the traditional 6-grade scale and the new 12-grade scale introduced by Papadopoulos and Imamura (2001). From $544 / 545$ up to now, only two reliable events of high intensity $K \geq 7$ have been reported, which very roughly indicates that the mean repeat time is $\sim 750$ years. Five reliable tsunamis of moderate intensity $4 \leq K<7$ have been observed from 1650 up to the present, which implies a recurrence of 72 years on the average. Although these calculations were based on a very small statistical sample of tsunami events, the repeat times found are consistent with the theoretical expectations from size-frequency relations. However, in the Black Sea there is no evidence of tsunamis of very high intensity $(K \sim 10)$ such as the $\mathrm{AD} 365,1303$ and 1956 ones associated with large earthquakes occurring along the Hellenic arc and trench, Greece, or the 1908 one in Messina strait, Italy. This observation, along with the relatively low tsunami frequency, indicates that the tsunami hazard in the Black Sea is low to moderate but not negligible. The tsunami hazard in the Azov Sea is very low because of the very low
\end{abstract}

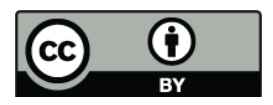

Correspondence to: G. A. Papadopoulos (papadop@gein.noa.gr) seismicity but also because of the shallow water prevailing there. In fact, only three possible tsunami events have been reported in the Azov Sea.

\section{Introduction}

The study of tsunami phenomena in the Black Sea region, including the Azov Sea, has been the subject of several papers. The first studies focused on the collection and analysis of mareograms of instrumentally recorded tsunami events, such as those of 1927, 1939 and 1966 generated by strong earthquakes (Dvoichenko, 1927, 1928; Markevich, 1928; Grigorash, 1959a, b; Grigorash and Korneva, 1969, 1972a). At a later stage, the studies were expanded to topics like the energy and spectra of tsunami waves (Grigorash and Korneva, 1970, 1972b; Korneva and Grigorash, 1979; Rangelov et al., 1987; Spassov and Rangelov, 1987), numerical hydrodynamic models (Engel, 1974; Choi et al., 1993; Dotsenko, 1993; Dotsenko and Konovalov, 1996; Yalciner et al., 2004), selection of the zones of tsunami generation (Christokov and TypkovaZaimova, 1979; Ranguelov et al., 1983; Kuran and Yalçiner, 1993; Selezov and Ostroverkh, 1997; Solov'eva et al., 2004; Solov'eva and Kuzin, 2005; Dotsenko and Eremeev, 2008) and tsunami height-earthquake magnitude relations (Pelinovsky, 1999) including some tsunami vulnerability and hazard estimates (Oaie et al., 2006a) and an attempt to calculate the repeat times of tsunami wave heights (Litvinenko and Strekalov, 2001). Schuiling et al. (2007) considered the case of the impact of a small asteroid that would hit the Black Sea region and showed that the potential emissions of toxic and flammable gases could be more disastrous to the region than the tsunami caused by the impact. On the other hand, Dotsenko and Eremeev (2008) dicussed the necessity and possibility of tsunami early warning in the Black Sea.

Published by Copernicus Publications on behalf of the European Geosciences Union. 


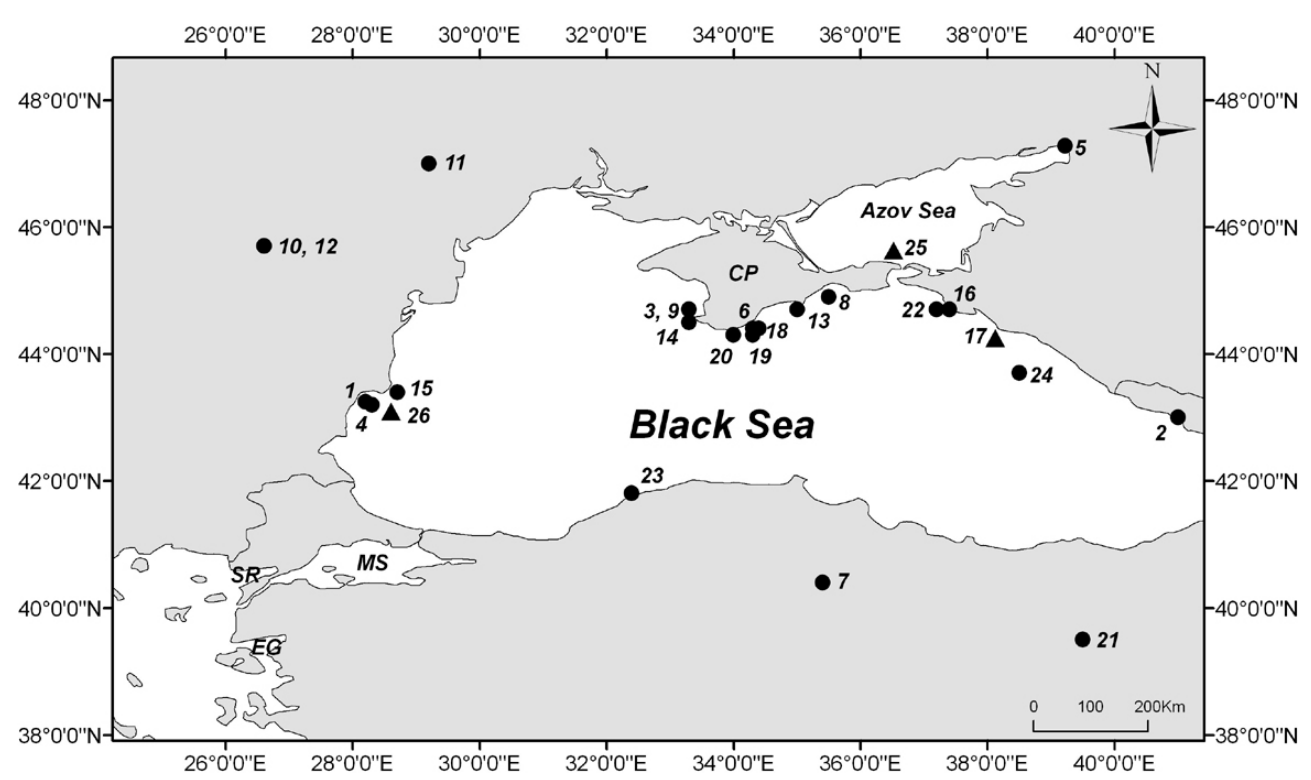

Fig. 1. Sources of tsunami generation in the Black Sea and the Azov Sea (for data see Table 1). Key: a solid circle is a seismic source, a solid triangle is a gravitative sliding source; $\mathrm{CP}=$ Caspian Peninsula, $\mathrm{EG}=$ Edremit Gulf, $\mathrm{MS}=$ Marmara Sea, $\mathrm{SR}=\mathrm{Saros} \mathrm{Bay}$.

Reviews of historical events and efforts for cataloguing tsunamis in the Black Sea were published by several authors (Grigorash, 1959a; Grigorash and Korneva, 1969; Ranguelov et al., 1985; Fomicheva et al., 1991; Kuran and Yalçiner, 1993; Dotsenko, 1995; Nikonov, 1997a, b; Pelinovsky, 1999; Altinok and Ersoy, 2000; Yalçiner et al., 2004; Oaie, 2006a). In addition, palaeotsunami studies revealed tsunami sediment deposits found at the north side of the Bulgarian Black Sea coast (Ranguelov, 2003; Ranguelov et al., 2008a).

In this paper we have compiled a new tsunami catalogue for the Black Sea and the Azov Sea by evaluating critically geological, archaeological, historical and instrumental data covering the time period from the 1st century $\mathrm{BC}$ up to the present. The catalogue was constructed following the format of the New European Tsunami Catalogue produced by a large group of specialists in a continuing effort within the frame of the EU GITEC, GITEC-TWO and TRANSFER research projects (e.g. Tinti and Maramai, 1996; Papadopoulos, 2003; Papadopoulos et al., 2007). A characteristic case is the key earthquake and tsunami event of 544/545 AD. This was an extreme event which was used for the tsunami risk assessment along the coastal zone of Balchick to the north of Varna, that is in one of the test-sites for the EU research project SCHEMA (2007-2010). In addition, we determined the most tsunamigenic areas in the study region and calculated roughly the mean repeat times of tsunamis.

The geography of the study region is illustrated in Fig. 1, which shows not only the Black Sea and the Azov Sea but also the NE Aegean Sea because some historical earthquakes reportedly caused tsunamis in both the Black Sea and the NE Aegean Sea.

\section{A new tsunami catalogue}

The tsunami catalogue presented here is a Quick-Look Catalogue (QLC) which consists of three sections: the Quick-Look Table (QLT), the Quick-Look Accounts File (QLAF) and the References File (RF). In this paper, RF includes the sections of Historical Sources and References. The QLT is arranged in Table 1 which shows that tsunami events were reported as early as 1 st century BC while the last event was observed in 2007.

\subsection{The Quick-Look Accounts File}

This is the second section of the QLC and is arranged as follows:

- [code number], date: see key in Table 1, place,

- coordinates of the source: geographic latitude $(\mathrm{N})$, longitude (E),

- cause: see key in Table 1 ,

- tsunami intensity: in 6-grade scale/in 12-grade scale,

- reliability: this concerns the tsunami event and scales from 1 to 4 (see Table 1).

As for the tsunami intensity, previous authors have tried to assign intensity for some tsunami events either in the old 6-grade Sieberg-Ambraseys scale (Ambraseys, 1962) or in the new 12-grade scale introduced by Papadopoulos and Imamura (2001) which is in use extensively worldwide. 
Table 1. Tsunami catalogue for the Black Sea and the Azov Sea. Key: ID=identification number, YY=year, MM=month, DD=day, $\mathrm{hh}=$ hour, $\mathrm{mm}=$ minute, $\mathrm{ss}=$ second, Rel = reliability of the occurrence time, Region BS = Black Sea, AS = Azov Sea, Lat = north latitude, Long = east longitude (both in degrees and minutes), Rel = accuracy of the location in minutes, $I=$ seismic intensity in MM, $M=$ surface-wave magnitude, $H=$ focal depth (in $\mathrm{km}$ ), $n=$ shallow earthquake, $i=$ intermediate-depth earthquake, Runup = maximum vertical tsunami run-up (in $\mathrm{cm}$ ), $k=$ tsunami intensity (in Sieberg-Ambraseys 6-grade scale), $K=$ tsunami intensity (in Papadopoulos-Imamura 12-grade scale), $\mathrm{Rel}=$ reliability of the tsunami event, $\mathrm{Y} / \mathrm{N}=$ an indication of whether the tsunami paremeters were revised $(\mathrm{Y})$ or not $(\mathrm{N})$ with respect to previous catalogues. The reliability of the time of occurrence is an expression of the time inaccuracy and is measured in units of the last entry of the time of occurrence (e.g. in years for the event number 3, in months for the event number 7 , in days for the event number 8 , minutes for the event number 16, etc.). Genesis causes classification: $E R=$ submarine earthquake, $E A=$ earthquake-associated, EL=earthquake landslide, ES = earthquake marine slide, GS = gravitative marine slide. For the reliability of the tsunami events a modified version of the tsunami reliability scale of Iida (1984) was adopted $(0=$ very improbable tsunami; this class practically is not in use since events of class 0 are not inserted in the catalogue; 1 =improbable tsunami, 2 =questionable tsunami, 3 = probable tsunami, $4=$ definite tsunami). Some additional symbol explanation is needed: (+) after a particular value means "equal to or larger than"; (-) after a particular value means "equal to or less than"; - before the year of occurrence means BC.

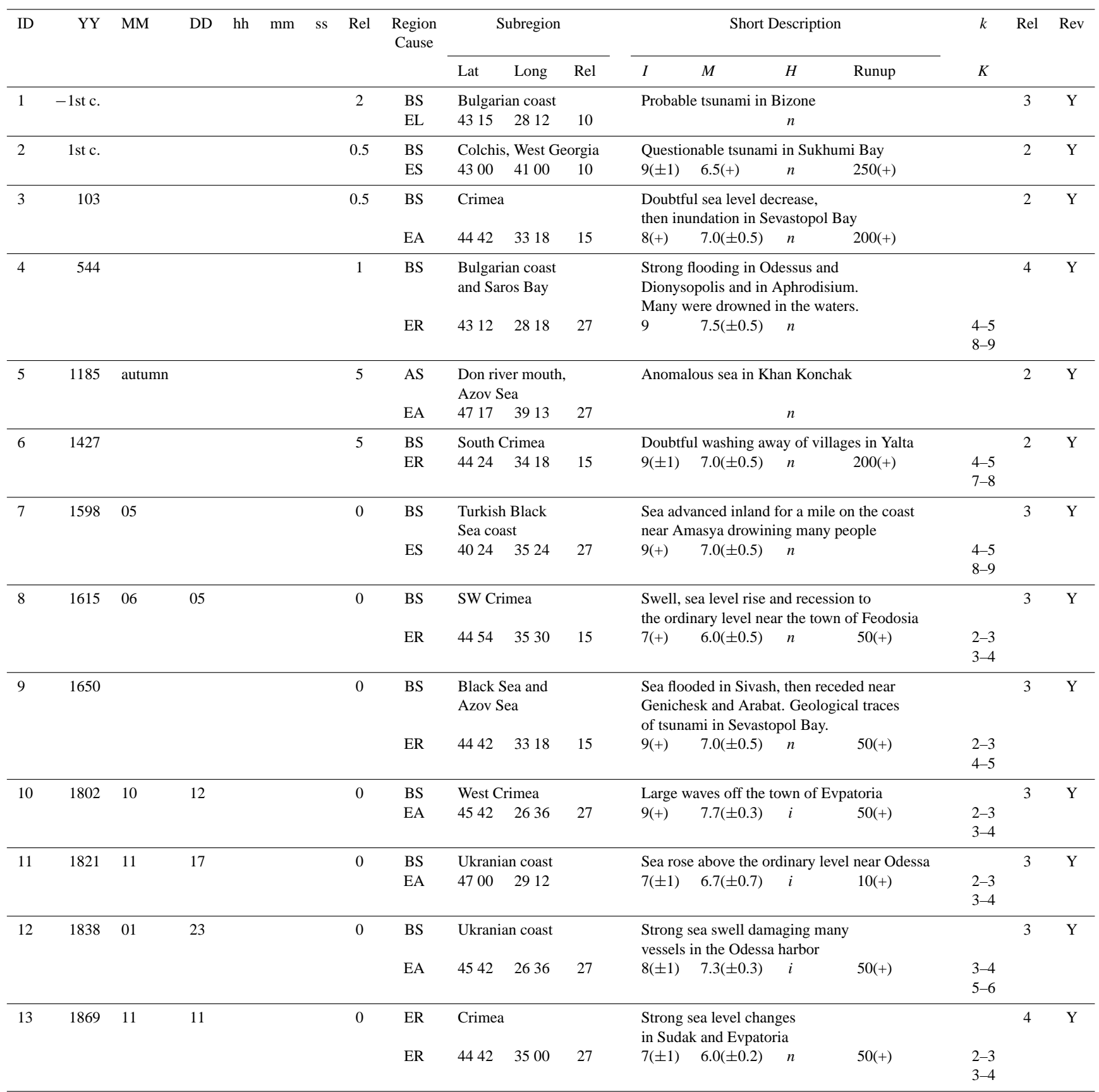


Table 1. Continued.

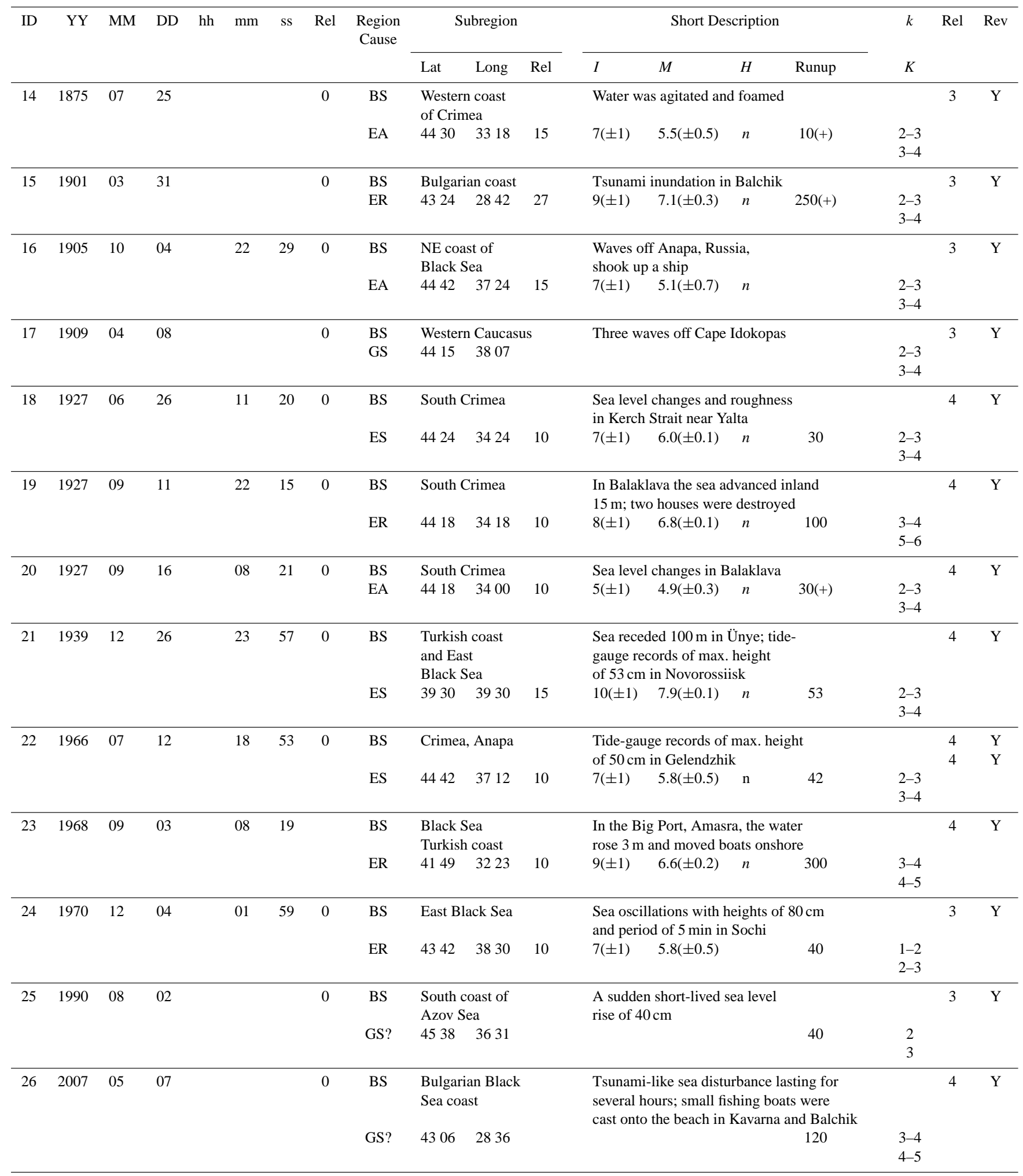


In this paper, when sufficient data were available we reevaluated intensities $k$ and $K$ in the 6-grade and 12-grade scales, respectively.

In the next lines 26 events are described and evaluated. Earthquake epicenters and other sources of tsunamigenic events were plotted in Fig. 1.

\section{[1], -1st century, Bizone (Kavarna, Bulgarian Black Sea coast)}

coordinates: $43^{\circ} 15^{\prime} \mathrm{N}, 28^{\circ} 12^{\prime} \mathrm{E}$

cause: EL

reliability: 3

This is a puzzling event which is mentioned by Strabo (64 BC-19 AD):

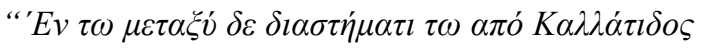

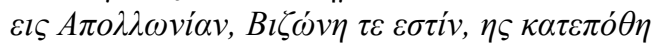

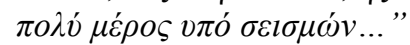

that is "Between Kallatis [today Magalia] and Apollonia [Sozoupolis] there is Bizone a large part of which submerged because of earthquakes...". Bizone was located where the today town of Kavarna is situated a few kilometers to the north of Balchik. Nikonov (1997b) reported that an early Armenian chronicler (Mowses Khorenatsi, 410 $491 \mathrm{AD}$ ) mentioned a sudden flooding of the southern shores of the Black Sea back in the legendary times of the 1st century BC.

According to Gergova et al. (1995), archaeological observations in the Thracian Necropolis at Sveshtari, NE Bulgaria, have established that in about the 3rd century BC a strong earthquake occurred there. These authors suggested that it was presumably the same earthquake that caused the nearby city of Bizone to slide into the sea. However, there is not any tsunami record. From the geoscientific point of view, Christoskov et al. (1995) suggested that geomorphological observations supported by the historical evidence indicated that the destruction of a large part of the Chirakman Cape, where ancient Bizone was situated, was caused by massive landslide induced by strong earthquakes in a period between the 1st and 4th century BC. During the same events the town of Dionisopolis, today Balchik, was probably damaged. Christoskov et al. (1995) concluded that they cannot exclude that the damage observed in Sveshtari area might been related to landsliding in Bizone. Again, there is no tsunami record in Bizone. Certainly, one may not rule out the reasonable scenario that massive landsliding caused a locally strong tsunami. In fact, tsunami evidence is provided by sediment deposits found to the north of Varna at $43^{\circ} 18^{\prime} \mathrm{N} / 28^{\circ} 18^{\prime} \mathrm{E}$. The deposits were radiocarbon dated at about 2000 years BP and attributed to a large magnitude $(M>7.0)$ earthquake (Ranguelov, 2003). However, the dating result is unstable and susceptible to large error. Levelling measurements indicated a wave run-up of 7-8 m.
We concluded that the strong earthquake which is evident through historical, archaeological and geomorphological evidence, was possibly the one that caused landslides and a local tsunami in Bizone probably during the 1st century BC. However, the little information available is not sufficient to estimate tsunami intensity.

Further references: Shebalin et al. (1974).

\section{[2], 1st century, Sukhumi Bay/Colchis (West Georgia)}

coordinates: $43^{\circ} 00^{\prime} \mathrm{N}, 41^{\circ} 00^{\prime} \mathrm{E}$

cause: ES

reliability: 2

Nikonov (1994, 1997a, b) and Dotsenko (1995), based on Russian sources, reported that the submergence of the town of Dioskuriada on the coast of Sukhumi Bay, Colchis, in West Georgia today, can be inferred from both local legends and town remains in the bay bottom. A rapid subsidence by $2-3 \mathrm{~m}$ was related to a catastrophic earthquake of $M \geq 6.5$ occurring in the earlier half of the 1st century. Nikonov (1997a) estimated that the event took place in AD $20 \pm 20$ but it is not absolutely clear how he reached that result. He suggested also that although no direct evidence for a tsunami was found, it may have occurred, judging from similar cases elsewhere on the globe, and that the run-up height exceeded $2.5 \mathrm{~m}$ the tsunami intensity being $k=\mathrm{IV}-\mathrm{V}$. This information was also repeated by Pelinovsky (1999) and Yalciner et al. (2004) who considered a tsunami intensity of $K=\mathrm{IV}-\mathrm{VI}$. However, we believe that the little information available is not sufficient to estimate tsunami intensity.

\section{[3], 103 AD, Sevastopol Bay (Crimea)}

coordinates: $44^{\circ} 42^{\prime} \mathrm{N}, 33^{\circ} 18^{\prime} \mathrm{E}$

cause: EA

reliability: 2

Nikonov (1997a, b) based his conclusions on the St. Clements' miracles as well as on archaeological evidence for damage caused in settlements in the Sevastopol Bay, Crimea, and suggested that a strong earthquake of $M \sim 7$ occurring at the beginning of the 2 nd century $\mathrm{AD}$, possibly in $103 \mathrm{AD}$, caused a strong tsunami in the bay. He estimated that the sea receded $500 \mathrm{~m}$, and occasionally $3-4 \mathrm{~km}$, and that the wave run-up was at least $2 \mathrm{~m}$. The intensity of this tsunami was estimated of $k=$ III (Nikonov, 1997a) or of $K=$ III-IV (Yalciner et al., 2004). We believe that the little information available is not sufficient to estimate tsunami intensity. 
[4], 544/545, Odessus and Dionysopolis (NE Bulgarian Black Sea), Aphrodisium (Saros Bay/NE Aegean Sea)

\author{
coordinates: $43^{\circ} 12^{\prime} \mathrm{N}, 28^{\circ} 18^{\prime} \mathrm{E}$ \\ cause: ER \\ tsunami intensity: 4-5/8-9 \\ reliability: 4
}

This is a key event in the historical earthquake and tsunami record of the Bulgarian Black Sea coast although it is puzzling from several points of view. Historical documentation of a possible tsunami event can be found in texts of the Byzantine chronographers Malalas, Cedrenus, Glykas, and Theophanes. In addition to that event, an earthquake occurred also in Cyzicus, today Banderma, in the south Marmara Sea (Fig. 1) (see reviews by Georgiades, 1904; Ambraseys, 1962; Antonopoulos, 1973; EvagelatouNotara, 1987/88; Guidoboni et al., 1994). Ambraseys (1962) considered the earthquake to have occurred in the winter of 542 and that the tsunami affected not only the Sea of Marmara and the Thracian coasts but also the Gulf of Edremit, which is strange enough, given the its distant location on the Aegean coast of Asia Minor (Fig. 1). Antonopoulos (1973) copied uncritically Ambraseys (1962). On the basis of the account of Theophanes, EvagelatouNotara (1987/88) accepted that the earthquake in Cyzicus occurred on 6 September 543.

A careful historical study was performed by Guidoboni et al. (1994) who distinguished between two separate events. The first was a destructive earthquake that hit Cyzicus on 6 September 543 , but there is very weak evidence for tsunami occurrence associated with the earthquake. The second event was a destructive sea wave taking place in 544/545 and flooding three coastal zones, two of today's Bulgarian coasts at the Black Sea and one at Thrace; namely at Odessus, later Tiveriopolis, and today's Varna; Dionysopolis, today Balchik, situated $20 \mathrm{~km}$ to the north of Varna; Aphrodisium, situated on the Thracian Peninsula at the Xeros (today Saros) Bay, Northeast Aegean Sea (Fig. 1). In fact, Theophanes (224) reported that "In this year [544/545] the sea advanced on Thrace by four miles [ca. $6 \mathrm{~km}]$ and covered it in the territories of Odessus and Dionysopolis and also Aphrodisium. Many were drowned in the waters. By God's command the sea then retreated to its own place" (English translation by Guidoboni et al., 1994). The descriptions found in Cedrenus (657) are similar; he placed the event again in 544/545 but Glykas (269) placed it in 557. Malalas (481) mentioned only briefly a destructive sea wave.

In his tsunami review, Nikonov (1997a, b) reproduced the Byzantine information and assumed that there was a tsunami with run-up heights exceeding 2-4 $\mathrm{m}$ caused by a shallow earthquake of $M=7.5 \pm 0.5$ occurring offshore at Varna in AD $543 \pm 1$. Pelinovsky (1999) and Yalciner et al. (2004) reproduced the earthquake parameters assumed by Nikonov (1997a). Zaitsev et al. (2002) copied Pelinovsky (1999). Yalciner et al. (2004) estimated that the tsunami intensity $K$ was of VIII-X degree in the new 12-grade scale introduced by Papadopoulos and Imamura (2001).

Altinok and Ersoy (2000) considered a confusing modification of the suggestion of Guidoboni et al. (1994) about two separate events and listed the first event, of reliability 2, occurring in 542 on the coast of Thrace but also in Edremit gulf with $k=4$, the estimation taken from Ambraseys (1962). They adopted 66 September 543 as the date of the second event occurring on Kapidag peninsula, in Erdek and Banderma but also in Edremit gulf. Altinok and Ersoy (2000) assigned reliability 3 to the second event. However, there is no evidence, neither in the Byzantine chronicles nor elsewhere, that the sea wave was also observed in Edremit gulf which implies that the account of Ambraseys (1962) was erroneus. Papazachos and Papazachou (2003) followed Guidoboni et al. (1994) and assumed also two events: one earthquake in Cyzicus on 6 September 543 and another in 544. For the second earthquake they assumed an epicenter of about $100 \mathrm{~km}$ to the south of the one proposed by Nikonov (1997a), its suggested magnitude being $7.0 \pm 0.5$, but they mentioned that the Byzantine sources do not explicitly attribute the wave to an earthquake.

Recent results of field observations in the archaeological site of Cybele Temple in Balchik have indicated possible inundation by the 544/545 sea wave. In fact, Ranguelov et al. (2008a) presented evidence that the Cybele Temple, which is of the Hellenistic period, was affected by fire and roof collapse, very possibly due to a strong earthquake, and very soon after the fire the floor was flooded by sea water which left behind a layer of sand and shells. Ranguelov et al. (2008a) suggested that there was an earthquake-tsunami event that affected the Cybele Temple in 543, which in fact is the $544 / 545$ one.

In summary, the large earthquake of 6 September 543 in Cyzicus, Marmara Sea, was unrelated to the sea wave which took place in 544/545 in the coastal zone of Thrace. In addition, the tsunami reported by some authors as occurring in 557 is a false event (see Appendix A). The sea wave of 544/545, which for all evidence had features of a tsunami, flooded the Bulgarian coastal zone of Odessus (Varna) and Dionysopolis (Balchik). This piece of information fits the field observations performed in the Cybele Temple in Balchik which indicated that the sea wave was a tsunami triggered by a strong earthquake. In the historical documents, however, Aphrodisium in Saros Bay, NE Aegean Sea, was also mentioned as being affected by the sea wave. Then, a question is raised as to the possibility of a strong earthquake having its source offshore at Varna-Balchik and causing a tsunami not only in the Black Sea Bulgarian coast, which is reasonable, but also in Saros Bay, Thracian coast, that is at a distance of about $330 \mathrm{~km}$ from the epicentre suggested by Nikonov (1997a). A possible mechanism for 
the tsunami initiation may involve a submarine landslide or slump in Saros Bay triggered by the earthquake. From empirical relations between earthquake magnitude and the maximum distance at which soil liquefaction or landslide could be triggered (Papadopoulos and Lefkopoulos, 1993; Papadopoulos and Plessa, 2000), it results that magnitude ranging between 7.3 and 7.6 is required. However, a smaller magnitude is required if the epicenter suggested by Papazachos and Papazachou (2003) is adopted. It is noteworthy that as analyzed later in 1901, an earthquake of estimated magnitude 7.1 occurred at nearly the same seismic source.

Further references: Milne (1912), Shebalin et al. (1974), Ambraseys (2009).

\section{[5], autumn 1185, Khan Konchak, Don river mouth,} Azov Sea

coordinates: $47^{\circ} 17^{\prime} \mathrm{N}, 39^{\circ} 13^{\prime} \mathrm{E}$

cause: EA

reliability: 2

This is an earthquake and tsunami event reported by Nikonov (1997b) to have occurred at Khan Konchak near the mouth of Don river in the Azov Sea. That author concluded about the earthquake and tsunami occurrence from the interpretation of a passage from "The Lay of Igor's Host", a 12th century epic poem describing Prince Igor's campaign against the nomad tribes. Nikonov (1997b) says: "The passage from the poem speaks of the sea bursting out at midnight and clouds, chased by hurricanes ..." and "the ground shook and moaned, rustling the tall grass, waking up the nomads in their camp ... This occurred in the autumn of $1185 \ldots$..." However, the description is not convincing, particularly for the tsunami event, and is thus considered of low reliability by us.

\section{[6], 1427, Yalta (South coast of Crimea)}

coordinates: $44^{\circ} 24^{\prime} \mathrm{N}, 34^{\circ} 18^{\prime} \mathrm{E}$

cause: ER

tsunami intensity: 4-5/7-8

reliability: 2

From legendary and folklore accounts of the 15th century, Nikonov (1997a, b) suggested that a very strong earthquake of $M=7.0 \pm 0.5$ associated with a tsunami occurred around 1427 on the south coast of Crimea. It is said that several villages were washed away around the town of Yalta. Nikonov (1997a) estimated the tsunami intensity at $k=$ III and the water level rise on the shore of at least $2 \mathrm{~m}$. Yalciner et al. (2004) estimated intensity at $K=$ II-IV. However, if the description "several villages were washed away" is correct, then the intensities $k$ and $K$ mentioned above underestimated the tsunami impact.

\section{[7], May 1598, Amasya (Central North Anatolia)}

coordinates: $40^{\circ} 24^{\prime} \mathrm{N}, 35^{\circ} 24^{\prime} \mathrm{E}$

cause: ES

tsunami intensity: 4-5/8-9

reliability: 3

Several documentary sources have indicated that in May 1598 a major earthquake caused destruction in Amasya and Çorum in central northern Anatolia. In some of the sources the descriptions may imply the occurrence of a strong tsunami on the Turkish Black Sea coast: “... the sea was driven back drowning a few thousand people in towns and villages"; and "... in Amasya [the ground] was cleaved engulfing many villages"; and "...the sea advanced inland for a mile on the coast of the Black Sea, drowining many people" (see review in Ambraseys and Finkel, 1995). Altinok and Ersoy (2000, p. 192) reproduced the above information and added that "The tsunami created by the earthquake in the gulf between Sinop and Samsun showed a wave height of approximately $1 \mathrm{~m}$ (Nikonov, 1997b)". However, we were unable to locate such an account in any of the papers of Nikonov (1997a, b). The only relevant piece of information found in Nikonov (1997b) is the plot on a map of the coastal spot where he suggested that the tsunami was observed near Sinop with the indication "tsunami occurring from remote earthquake". However, no reference is given. Ambraseys (2009) noted that the occurrence of a seismic sea wave on the coast of the Black Sea, $100 \mathrm{~km}$ to the north of Amasya, is difficult to associate with the earthquake, unless it was associated with a massive submarine landslide. The intensity of this tsunami was estimated by Yalciner et al. (2004) to be $K=$ II-IV. However, if the description that many people were drowned by the wave is correct, then the tsunami intensity has been underestimated and, therefore, we assigned a tsunami intensity of a higher degree.

Further references: Milne (1912), Shebalin et al. (1974).

\section{[8], 5 June 1615, Feodosia (SW Crimea)}

\author{
coordinates: $44^{\circ} 54^{\prime} \mathrm{N}, 35^{\circ} 30^{\prime} \mathrm{E}$ \\ cause: ER \\ tsunami intensity: 2-3/3-4 \\ reliability: 3
}

Based on Armenian chronicles, Nikonov (1997a) listed an earthquake of $M=6.0 \pm 0.5$ and an associated tsunami occurring on 5 June 1615 on the southeastern coast of Crimea with the next description: "Swell, sea level rise and recession to the ordinary level near the town of Feodosia." $\mathrm{He}$ also estimated the water level rise to be 0.5 to $1.0 \mathrm{~m}$ and the tsunami intensity $k=$ II. According to Yalciner et al. (2004), the tsunami intensity $K$ was estimated between II and IV. We have estimated it as shown above. 


\section{[9], 1650, Sivash (Azov Sea)}

coordinates: $44^{\circ} 42^{\prime} \mathrm{N}, 33^{\circ} 18^{\prime} \mathrm{E}$

cause: ER

tsunami intensity: $2-3 / 4-5$

reliability: 3

This was an earthquake $(M=7.0 \pm 0.5)$ and tsunami event reported by Nikonov (1997a) to have occurred in 1650 in the western shores of the Azov Sea as well as in the Black Sea: "Sea flooded the shore to connect with the Sivash, then the water receded near Genichesk and Arabat. Geological traces of tsunami in the Sevastopol Bay" in Crimea. He also estimated a water level rise of 0.5 to $1.0 \mathrm{~m}$ and a tsunami intensity $k$ of degree III. We have estimated it as shown above.

\section{[10], 12 October 1802, Evpatoria (western Crimea)}

coordinates: $45^{\circ} 42^{\prime} \mathrm{N}, 26^{\circ} 36^{\prime} \mathrm{E}$

cause: EA

tsunami intensity: $2-3 / 3-4$

reliability: 3

This was a large, intermediate-depth earthquake of an estimated magnitude of 7.7 occurring at the Vrancea seismic source, Romania (Constantinescu and Marza, 1989; we adopted focal parameters estimated by them). The earthquake was perceptible at very long distances, from St. Petersburg to the north, to Ithaki island in Ionian Sea to the south, but it was highly destructive in Bucharest (von Hoff, 1841; Mallet, 1855). The very long radius of perceptibility is a common feature of the intermediate-depth earthquakes of Vrancea as well as those of the Hellenic arc and elsewhere.

From Russian sources, Nikonov (1997a) listed the earthquake and an associated tsunami: "Large waves off the town of Evpatoria, at western coast of Crimea, in calm weather." However, the description for large waves is not compatible with the same author's estimated maximum water level rise of $\geq 0.5 \mathrm{~m}$. The estimated tsunami intensity was $k=$ II. The mechanism which triggered the waves was possibly a submarine slump caused by the earth shaking. From empirical relations between earthquake magnitude and the maximum distance, $R$, at which soil liquefaction or landslide could be triggered (see similar analysis for the event [4] of 544/545 AD), it results that for $M=7.7$ we get $R=340 \mathrm{~km}$ and $R=620 \mathrm{~km}$, respectively. The epicentral distance of Evpatoria is about $750 \mathrm{~km}$, which is very long. However, it should be noted that the above empirical relations are valid for shallow earthquakes since no such relations were produced for intermediate-depth earthquakes due to the scarcity of data. On the other hand, Evpatoria is situated in the area of maximum seismic perceptibility.
Therefore, we do not rule out that the sea wave in that locality was due to a submarine ground failure triggered by the earth shaking.

Further references: Milne (1912), Shebalin et al. (1974), Yalciner et al. (2004).

\section{[11], 17 November 1821, Odessa (Ukraine)}

coordinates: $47^{\circ} 00^{\prime} \mathrm{N}, 29^{\circ} 12^{\prime} \mathrm{E}$

cause: EA

tsunami intensity: $2-3 / 3-4$

reliability: 3

This was a strong earthquake which caused some damage to buildings at Jassy, Moldavia, and was felt in Kiev and other Ukranian localities and as far as Tiflis in Georgia (von Hoff, 1841; Mallet, 1855). From Russian sources, Nikonov (1997a) listed the earthquake with an estimated magnitude of $6.7 \pm 0.7$ and an associated sea level disturbance: "Sea rose above the ordinary level near the town of Odessa by more than $10 \mathrm{~cm}$; $k=I I$." A similar description, again from Russian sources, was given by Dotsenko (1995) and Pelinovsky (1999) and it was repeated by Yalciner et al. (2004). In the catalogue of Shebalin et al. (1974), the earthquake was classified as one of intermediate-depth and its epicentral location was estimated to be the same as that of the previous event of 1802. These parameters were also adopted by Nikonov (1997a). Then again, the question is raised of the mechanism that caused the sea level rise in Odessus at an epicentral distance of about $440 \mathrm{~km}$. We repeated the calculations as we had done with the previous event of 1802 and found that for $M=6.7$, a maximum distance at which soil liquefaction or landslide could be triggered is $R=80 \mathrm{~km}$ and $R=$ $110 \mathrm{~km}$, respectively. These distances are too short even for intermediate-depth earthquakes to cause ground failures $440 \mathrm{~km}$ away from the epicenter. Then, two alternatives might be considered. The first is that the epicenter is correctly placed and the sea disturbance was only a standing wave (seiche) caused by the seismic ground vibration. Another possibility is that the earthquake was not associated with the Vrancea seismic source, that the above epicenter is not correctly placed and that it should be shifted more to the North. This last solution is our favoured one. Then, the sea disturbance could be attributed equally either to a submarine slump or to a seiche.

Further references: Milne (1912). 


\section{[12], 23 January 1838, Odessa (Ukraine)}

coordinates: $45^{\circ} 42^{\prime} \mathrm{N}, 26^{\circ} 36^{\prime} \mathrm{E}$

cause: EA

tsunami intensity: $3-4 / 5-6$

reliability: 3

This was another large, intermediate-depth earthquake of an estimated magnitude of 7.3 occurring at the Vrancea seismic source, Romania (Constantinescu and Marza, 1989; we adopted focal parameters estimated by them). The earthquake became perceptible at long distances but not so far away as the 1802 one (von Hoff, 1841; Mallet, 1855). In Transylvania the buildings first rocked from side to side and then the walls cracked and fell. From Russian sources, Nikonov (1997a) listed the earthquake and an associated sea disturbance: "Strong sea swell damaging many vessels in the Odessa harbor." He estimated a tsunami intensity of $k=$ II. Yalciner et al. (2004) based their findings on the information provided by Nikonov (1997a) and estimated a tsunami intensity of $K=$ VII-VIII degree on the new 12 grade scale of Papadopoulos and Imamura (2001). On the same scale, we prefered to assign a conservative intensity as high as V-VI degree.

Further references: Milne (1912), Shebalin et al. (1974).

\section{[13], 11 November 1869, Sudak and Evpatoria (Crimea)}

coordinates: $44^{\circ} 42^{\prime} \mathrm{N}, 35^{\circ} 00^{\prime} \mathrm{E}$

cause: ER

tsunami intensity: $2-3 / 3-4$

reliability: 4

Based on Russian sources, Nikonov (1997a) listed a shallow earthquake $(M=6.0 \pm 0.2)$ and a tsunami event in Crimea: "Town of Sudak: a violent horizontal recession of the sea by $2 \mathrm{~m}$ and a slow return to the ordinary level in 10 min. A strong tidal wave as high as $1 \mathrm{~m}$ near the town of Evpatoria." He estimated tsunami intensity to be $k=$ I-III. Again from Russian sources, Dotsenko (1995) described the event shortly as follows: "The earthquake had intensity 7-8 in Yalta, Sevastopol and Sudak. The sea was stormy." (see also in Pelinovsky, 1999). Yalciner et al. (2004) summarized the above information and estimated that the intensity of this tsunami can be considered at $K=\mathrm{II}-\mathrm{IV}$. We estimated it as shown above. Earthquake parameters were adopted from Nikonov (1997a).

Further references: Montandon (1953).

\section{[14], 25 July 1875, Western coast of Crimea}

\author{
coordinates: $44^{\circ} 30^{\prime} \mathrm{N}, 33^{\circ} 18^{\prime} \mathrm{E}$ \\ cause: EA \\ tsunami intensity: $2-3 / 3-4$ \\ reliability: 3
}

A Russian source indicated that a moderate earthquake of $M=5.5 \pm 0.5$ caused some sea disturbance with estimated tsunami intensity $k=$ I-III: "Western coast of Crimea. Water was agitated and foamed" (Nikonov, 1997a). Yalciner et al. (2004) summarized the information provided by Nikonov (1997a) and estimated that the intensity of this tsunami could be considered at $K=$ II-III. We estimated it as shown above. The earthquake parameters were adopted from Nikonov (1997a).

Further references: Milne (1912), Montandon (1953).

\section{[15], 31 March 1901, Balchik (North Bulgarian Black Sea coast)}

coordinates: $43^{\circ} 24^{\prime} \mathrm{N}, 28^{\circ} 42^{\prime} \mathrm{E}$

cause: ER

tsunami intensity: 2-3/3-4

reliability: 3

A large earthquake of $M=7.1$ and maximum intensity of $X$ degree (MSK) or IX-X (EMS) occurred offshore ShablaKaliakra, NE Bulgaria, causing surface landslides of several $\mathrm{km}$ and subsidence of about $3 \mathrm{~m}$. "The boats in the port of Balchik were uplifted about the same altitude" (Ranguelov, 1996). This information came from an eyewitness reviewed in early 70's by B. Ranguelov. Tsunami inundation with a maximum height of about $2.5-3 \mathrm{~m}$ was reported by an eyewitness at the Balchik port (Grigorova and Grigorov, 1964).

\section{[16], 4 October 1905, Anapa (NE Black Sea)}

coordinates: $44^{\circ} 42^{\prime} \mathrm{N}, 37^{\circ} 24^{\prime} \mathrm{E}$

cause: EA

tsunami intensity: $2-3 / 3-4$

reliability: 3

From Russian sources, sea waves were described in association with a moderate $(M=5.1)$ earthquake near Anapa: "NE coast of Black Sea near the town of Anapa. Waves off Anapa shook up a ship. Maximum water level rise $\geq 0.5 \mathrm{~m}, k=I I$. Earthquake magnitude $M=5.1 \pm 0.7$ " (Nikonov, 1997a); "Submarine earthquake of $M=7$ was registered in the vicinity of the town of Anapa, Russia. The waves were so large at the sea surface that they bounced the vessel. Five shocks were felt" (Grigorash and Korneva, 1969; also Dotsenko, 1995; Pelinovsky, 1999). The intensity of this tsunami can be considered at $K=$ III-VI (Yalciner et al., 2004). 


\section{[17], 8 April 1909, Cape Idokopas (Western Caucasus)}

\author{
coordinates: $44^{\circ} 15^{\prime} \mathrm{N}, 38^{\circ} 07^{\prime} \mathrm{E}$ \\ cause: GS \\ tsunami intensity: $2-3 / 3-4$ \\ reliability: 3
}

Nikonov (1997a) based his findings on a Russian source and described an aseismic case of sea waves observed off the coast of Western Caucasus: "Off the NE coast of Black Sea near Cape Idokopas. Three waves off Cape Idokopas." Although no information was provided about the features of the wave, he suggested that tsunamis may arise in the Black Sea not only from large seismic events, but also from underwater slides, and that this was most likely the cause of the 1909 tsunami when the wave height in the open sea above the continental slope reached $3-5 \mathrm{~m}$. To support his suggestion, Nikonov (1997a) noticed that an underwater cable broke twice due to moderately sized earthquakes that occurred in the NE Caucasus in 1870. He added also that abundant turbidites in near-surface sea deposits off the Caucasian, Crimean, and Bulgarian coasts also confirmed the conclusion that underwater slides occurred there. In fact, a recent case observed along the Bulgarian coast in 2007 was described and studied by Ranguelov et al. (2008b) (see details later). The generation of tsunamis from submarine landslides or slumps is well-known also in the eastern Mediterranean Sea (Papadopoulos, 2003; Perissoratis and Papadopoulos, 1999) but also elsewhere (e.g. Tappin et al., 1999).

\section{[18], 26 June 1927, Yalta (South Crimea)}

coordinates: $44^{\circ} 24^{\prime} \mathrm{N}, 34^{\circ} 24^{\prime} \mathrm{E}$

cause: ES

tsunami intensity: $2-3 / 3-4$

reliability: 4

Data published in Russian sources have shown that a strong earthquake with a magnitude of 6.0 occurred possibly on the submarine slope south of Yalta and caused a local tsunami on the south coast of Crimea. Dotsenko (1995) and Dotsenko and Konovanov (1996) published data from Soviet tide-gauge stations that recorded the event with maximum height of $24 \mathrm{~cm}$ at Yalta station, the heights in another five stations ranging from 6 to $14 \mathrm{~cm}$ (Table 2). Eyewitnesses noted that the sea bottom topography changed with the earthquake by a downward shift of silt on submarine rocks along the Crimean coastal zone, and that "changes in the sea level in the western and eastern parts of the Kerch Strait and, in general, the sea was stormy and rough throughout the entire earthquake" (Dotsenko, 1995, from various Russian sources; also Pelinovsky, 1999). According to the data collected by Nikonov (1997a), in the Gurzuf village the sea receded by $1.5 \mathrm{~m}$, then came back again to the shore. In Yalta, the sea level fell by $0.18 \mathrm{~m}$ and then rose by
$0.16 \mathrm{~m}$. In Sevastopol, a maximum sea level rise of 0.16$0.32 \mathrm{~m}$ was observed. These values correspond to readings in tide records (Table 2). In Alupka, the sea receded and then returned onto the shore and overwhelmed the beach. Sea disturbance was also reported from Feodosia, Alushta, Tuapse, Sudak, Novorossiisk and Kerch. The intensity of this tsunami was estimated at $k=$ II (Nikonov, 1997a) or $K=$ IIIIV (Yalciner et al., 2004). Among the written sources that Nikonov (1997a) listed for this tsunami event is that of Antonopoulos (1979), which, however, is a false reference because no Black Sea tsunamis are studied in the paper of Antonopoulos (1979) .

Considering the eyewitness acounts, we are in favour of the suggestion that the tsunami of 26 June 1927 was triggered by submarine slumps initiated by the earthquake.

\section{[19], 11 September 1927, South Crimea}

coordinates: $44^{\circ} 18^{\prime} \mathrm{N}, 34^{\circ} 18^{\prime} \mathrm{E}$

cause: ER

tsunami intensity: $3-4 / 5-6$

reliability: 4

After the event of 26 June 1927, an even larger and destructive earthquake of magnitude 6.5 occurred in the Crimean region. The epicenter co-ordinates were situated on the slope of the Black Sea trough, $20 \mathrm{~km}$ south-east of Yalta. In the open sea, near the seismic source, fishermen observed sea surface variations and roughness (Dotsenko, 1995; Pelinovsky, 1999). From several Russian sources reviewed by Nikonov (1997a) it results that in Balaklava, to the south of Sevastopol, the sea receded in the bay by 0.6$1.0 \mathrm{~m}$, then rushed onto the shore and overwhelmed a vast expanse $(15 \mathrm{~m})$ rising by $0.5 \mathrm{~m}$; two houses were destroyed. In Sevastopol, ebb up to $0.5 \mathrm{~m}$ was observed, while in Yalta first a rapid fall and then oscillation at $0.37 \mathrm{~m}$ were reported. Sea level rise was also reported in other localities (Table 2).

The earthquake was accompanied by tsunami waves recorded on tide gauges with height of $39 \mathrm{~cm}$ in Evpatoria, $35 \mathrm{~cm}$ in Yalta, $23 \mathrm{~cm}$ in Sevastopol, $18 \mathrm{~cm}$ in Novorossiisk and Tuapse, and $20 \mathrm{~cm}$ in Batumi (Dotsenko and Konovanov, 1996). The intensity of this tsunami was estimated as $k=\mathrm{II}$ by Nikonov (1997a).

\section{[20], 16 September 1927, South Crimea}

\author{
coordinates: $44^{\circ} 18^{\prime} \mathrm{N}, 34^{\circ} 00^{\prime} \mathrm{E}$ \\ cause: EA \\ tsunami intensity: 2-3/3-4 \\ reliability: 4
}

An aftershock,magnitude of 4.9 of the mainshock, 12 September 1927, caused the sea water to recede and then to rise more than $0.3 \mathrm{~m}$ in the bay of Balaklava. The intensity 
of this tsunami was estimated at $k=$ II (Nikonov, 1997a) or $K=$ III-IV (Yalciner et al., 2004) in the new 12-grade scale introduced by Papadopoulos and Imamura (2001).

\section{[21], 26 December 1939, Fatsa (Black Sea coast of North Turkey)}

coordinates: $39^{\circ} 30^{\prime} \mathrm{N}, 39^{\circ} 30^{\prime} \mathrm{E}$

cause: ES

tsunami intensity: 2-3/3-4

reliability: 4

This earthquake $(M=7.9)$ occurred at 23:57 GMT of 26 December 1939 rupturing a long segment of the North Anatolian Fault. It was one of the largest earthquakes ever recorded instrumentally in the eastern Mediterranean Sea. A description of the earthquake and its effects were summarized by Richter (1956, p. 612-613) as follows. Loss of life was between 20000 and 30000 although a figure of 40000 was reported (Altinok and Ersoy, 2000); over 30000 dwellings were destroyed. The four largest communities where the majority of structures were destroyed were (from east to west) Ercincan, Susehri (Endires), Koyulhisar (Misas), Reşadiye, and Niksar (Neocaesarea). Faulting and high intensity extended from east of Erzincan to near Niksar, about $340 \mathrm{~km}$. The meizoseismal zone, following the fault line, was about $15 \mathrm{~km}$ wide. The area over which the shock was felt was roughly elliptical, with major and minor axes of about 1300 and $600 \mathrm{~km}$. At some points in and near towns there was clear evidence of strike-slip faulting showing right-hand offset, amounting up to $3.7 \mathrm{~m}$. According to Richter (1956) the best available epicenter as determined by Gutenberg for the great earthquake is near $39^{1} / 2^{\circ} \mathrm{N}, 39^{1} / 2^{\circ} \mathrm{E}$, near Erzincan. This epicenter is at a distance of about $160 \mathrm{~km}$ from the closest Black Sea coast in north Turkey.

Parejas et al. (1942; after Altinok and Ersoy, 2000) mentioned that a person in Fatsa, to the east of Sinop, wanted to dive into the sea instinctively at the time of the earthquake, but he was not able to reach the sea because it had receded about $50 \mathrm{~m}$. After a while, when the sea came back, the edge of the coast advanced $20 \mathrm{~m}$. According to observations collected by Altinok and Ersoy (2000) during the earthquake the sea receded $100 \mathrm{~m}$ in Ünye and sunken rocks appeared for the first time. The sea also receded for 50-60 s in Giresun. Moreover, in Ordu, the people at the harbour saw that the sea initially became quiet, then receded about $15 \mathrm{~m}$. The level of the sea returned to normal in 5-10 $\mathrm{min}$.

The tsunami crossed mainly the eastern part of the Black Sea and was recorded on tide gauges in Soviet harbors with a height of $50 \mathrm{~cm}$ in Sevastopol as well as in Novorossiisk $(53 \mathrm{~cm})$, in Tuapse $(40 \mathrm{~cm})$ and in other stations (Grigorash and Korneva, 1969, 1972; Dotsenko, 1995; Nikonov, 1997a; Pelinovsky, 1999) (Table 2). Yalciner et al. (2004) estimated that the intensity of this tsunami can be considered $K=$ III-V while Nikonov (1997a) tentatively estimated $k=\mathrm{IV}$.

That the rupture zone of the earthquake is situated a long distance inland from the north coast of Turkey, where the tsunami was observed, makes it difficult to understand the tsunami generation mechanism. This is exactly why Richter (1956) noted that since the mainshock epicenter was certainly on land, the sea motion in Fatsa is important. Grigorash and Korneva (1969) noted that the tsunami began with the rise of the sea level in all stations except Batumi, which was the nearest USSR tide gauge to the earthquake epicenter. This station first recorded a fall of the sea level beginning at 23:57 GMT on 26 December, exactly at the time of the mainshock. Those authors compared the calculated wave travel-times with the observed ones and suggested that the tsunami was either on the Black Sea shore near the Turkish coast, between Batumi and Sinop, or inland, and it is unknown if the tsunami was caused by tectonic movement or by landslide. Nikonov (1997a) suggested that although no landslide-triggered tsunamis by teleseismic inland earthquakes have been reported in the Black Sea, "they can be assumed for the East Anatolia earthquake of 1939 ..." Pelinovsky (1999) proposed three possibilities as for the tsunami source: (i) ground rupture, (ii) secondary fault believed to be associated with the dislocation motion in the Black Sea, (iii) submarine landslide triggered by the earthquake in the Black Sea. Yalciner and Pelinovsky (2004) investigated the possible source mechanism by comparing results of the numerical modeling of the tsunami with the observational data and the instrumental records, but they did not reach a conclusive result.

Our favoured solution is the one which involves a coseismic sediment slump at the continental slope of the Black Sea north coast of Turkey between Sinop and Batumi. This scenario is supported by the fact that a negative wave phase was first recorded at Batumi, a feature which is characteristic at stations situated at the shore facing the tsunami source of landslide type (e.g. Papadopoulos et al., 2007). The empirical relations of $M / R$ for co-seismic ground failures applied earlier in the examination of the events of $544 / 545 \mathrm{AD}$ and 1802, indicate that for $M=7.9$ distance $R$ exceeds $160 \mathrm{~km}$, that is the seismic triggering of submarine slump between Sinop and Batumi was quite possible.

An unusual hypothesis was put forward by Bernaerts (2005) who suggested that the tsunami may have contributed, though in a small measure, to the wider regional conditions leading to the severe war winter of 1939/40. According to this suggestion the tsunami waves released enough "energy" stored at sea surface to enable the formation of forceful low pressure on the north coast of Turkey within hours of the quake. At a level of 20 to $40 \mathrm{~m}$ below the surface, the Black Sea still has a substantial portion of the summer heat at hand in December. Further, its surface and deep-water bodies are of different hydro 
Table 2. Parameters of Black Sea tsunamis. Key: $h=$ wave height (in $\mathrm{cm}$ ), $T=$ characteristic period of wave (in min), $p=$ polarity of first wave motion in the station, $N=$ number of the highest wave, $t=$ time of wave propagation from the tsunami source to the station, all these parameters were recorded by Soviet tide-gauge stations and collected by Dotsenko (1995) and Dotsenko and Konovalov (1996) from several sources, including Grigorash (1959a, b, 1972), Grigorash and Korneva (1969, 1972a, b) and Fomicheva et al. (1991); $H=$ wave height (in cm) summarized by Nikonov (1997a) from records of Soviet tide-gauge stations (Grigorash, 1972; Grigorash and Korneva, 1969, 1972b) and observations from a long number of other Russian sources. One may observe that in some instances the wave heights summarized by Nikonov (1997a) are not consistent with those summarized by Dotsenko (1995) and Dotsenko and Konovalov (1996).

\begin{tabular}{|c|c|c|c|c|c|c|c|c|c|c|c|c|c|c|c|c|}
\hline \multirow{2}{*}{$\begin{array}{l}\text { Station/ } \\
\text { Observation } \\
\text { point }\end{array}$} & \multicolumn{6}{|c|}{26.06 .1927} & \multicolumn{6}{|c|}{ 11.09.1927 } & \multicolumn{2}{|c|}{26.12 .1939} & \multicolumn{2}{|c|}{ 12.07.1966 } \\
\hline & $h$ & $T$ & $p$ & $N$ & $t$ & $H$ & $h$ & $T$ & $p$ & $N$ & $t$ & $H$ & $h$ & $H$ & $h$ & $H$ \\
\hline Odessa & & & & & & & 5 & 9 & + & 3 & 189 & & & & & \\
\hline Evpatoria & 14 & 22 & + & 2 & 76 & & 39 & 45 & + & 1 & 105 & & & & & \\
\hline Balaklava & & & & & & & & & & & & $50-100$ & & & & \\
\hline Sevastopol & & & & & & $16-32$ & 23 & 45 & + & 2 & 35 & $\geq 10$ & 50 & & & \\
\hline Yalta & 24 & 22 & + & 2 & 8 & 16 & 35 & 35 & - & 2 & 9 & 37 & 14 & & 2 & 2 \\
\hline Opasnoe & & & & & & & & & & & & & & & & 5 \\
\hline Feodosia & 8 & 20 & + & 3 & 48 & weak wave & 13 & 30 & + & 2 & 59 & & 25 & & 10 & $3-4$ \\
\hline Alupka & & & & & & 7 & & & & & & & & & & \\
\hline Kerch & 6 & 23 & + & 1 & 159 & & 13 & 50 & + & 1 & 184 & 13 & 24 & & 9 & 3 \\
\hline Sudak & & & & & & 8 & & & & & & & & & & \\
\hline Novorossiisk & 8 & 28 & + & 2 & 59 & 6 & 18 & 50 & + & 3 & 54 & $<20$ & 53 & 53 & & \\
\hline Gelendzhik & & & & & & & & & & & & & & & 42 & 21 \\
\hline Alushta & & & & & & $<2$ & & & & & & & & & & \\
\hline Tuapse & 8 & 10 & + & 3 & 39 & wave & 19 & 8 & + & 2 & 49 & 15 & 40 & 40 & 8 & 5 \\
\hline Batumi & & & & & & & 20 & 8 & + & 3 & 96 & & 7 & & 1 & 1 \\
\hline Mariupol & & & & & & & 18 & 30 & + & 3 & 290 & 18 & & & & 3 \\
\hline Fats & & & & & & & & & & & & & & 100 & & \\
\hline
\end{tabular}

structure, the upper layer being rather thin and limited to about $100-150 \mathrm{~m}$, with certainly enough heat for an active cyclone towards the end of December.

\section{[22], 12 July 1966, Anapa (Crimea)}

coordinates: $44^{\circ} 42^{\prime} \mathrm{N}, 37^{\circ} 12^{\prime} \mathrm{E}$

cause: ES

tsunami intensity: 2-3/3-4

reliability: 4

This was a tsunami triggered by a moderate earthquake $(M=5.8)$ which occurred about $10 \mathrm{~km}$ offshore Anapa at a focal depth of $55 \mathrm{~km}$. The tsunami wave was recorded by Soviet tide gauges as summarized in Table 2. One may observe that contradictory wave amplitudes were reported by different authors. The highest amplitudes were $42 \mathrm{~cm}$ in Gelendzhik, at $50 \mathrm{~km}$ to the south, and $10 \mathrm{~cm}$ in Feodosia at $60 \mathrm{~km}$ across the Crimean Peninsula. The intensity of this tsunami can be considered $k=\mathrm{I}$ (Nikonov, 1997a) or
$K=$ III-V (Yalciner et al., 2004). The relatively small earthquake magnitude disfavours tsunami generation by coseismic faulting. Hence, submarine slump is a more likely mechanism.

At this point, it is of relevance to note that Dotsenko and Ingerov (2007a) studied the digitized mareograms and the spectral features of the 26 July 1927, 11 September 1927, 26 December 1939 and 12 July 1966 tsunami waves. They found that as a rule, tsunami waves were characterized by the initial elevation of the sea level and that the height of the first wave was not the maximum one. The maximum heights of the recorded tsunami waves at the points of observation did not exceeded $52 \mathrm{~cm}$. For the major part of points on the sea coast, they observed a noticeable trend towards increase in the heights of waves with the magnitude of the earthquake. The typical periods of tsunami waves and background variations of the sea level lie within the intervals 8-39 min and 28-193 min, respectively. The same authors (Dotsenko and Ingerov, 2007b) performed analysis of the time spectra of the four tsunamis. For the analysis 
of the spectra, they used digitized mareograms obtained for 12 points of the Black Sea coast. The obtained spectra were found, as a rule, multimode with one to four spectral maxima. One maximum corresponds to the periods typical of tsunami waves and the other maxima correspond to the oscillations of the sea level with lower frequencies. It seems likely that the tsunami events were accompanied by lowfrequency oscillations of the level caused by the atmospheric forcing, seiches, or other factors. In numerous cases, the oscillations from the predominant energy range lie outside the characteristic range of periods of the tsunami waves.

\section{[23], 3 September 1968, Amasra (Black Sea coast of north Turkey)}

coordinates: $41^{\circ} 49^{\prime} \mathrm{N}, 32^{\circ} 23^{\prime} \mathrm{E}$

cause: ER

tsunami intensity: $3-4 / 4-5$

reliability: 4

The Bartin earthquake was strong $(M=6.6)$ and destructive, killing 24 persons. During this earthquake on the Black Sea north coast of Turkey, the precipitous coastline between Amasra and Çakraz uplifted by $35-40 \mathrm{~cm}$, and the sea level lowered on the coastal rock. Because of this mussels and moss appeared (Ketin and Abdüsselamoğlu, 1969; after Altinok and Ersoy, 2000). Lander (1969) reported that the sea receded 12 to $15 \mathrm{~m}$ in Çakraz at the onset of the earthquake and never returned entirely to its original level. In the Big Port of Amasra the water first drew back $1.5 \mathrm{~m}$. At the same time fish were jumping on the shore but later the water rose $3 \mathrm{~m}$, coming up to houses at the coast and taking boats near a coffee house. At the Big Port also, subsidence of $\sim 25 \mathrm{~cm}$ occurred at the landing port for loading the submarines. Wedding (1968; after Altinok and Ersoy, 2000) stated that the sea inundated $100 \mathrm{~m}$ in Amasra and after $14 \mathrm{~min}$ the second wave inundated the shore about $50-60 \mathrm{~m}$. This wave dragged many objects and caused many boats to be stranded. The silent and unstopped progression of the sea frightened the population. The reason for this progression was most probably the uplifting around Çakraz. According to Yalciner et al. (2004), the intensity of this tsunami can be considered as $K=\mathrm{III}-\mathrm{V}$ on the new tsunami intensity scale of Papadopoulos and Imamura (2001).

The coastal uplift between Amasra and Çakraz is consistet with the fact that the modelling of $P$ and SH seismic waves showed earthquake focal mechanism of thrust type and very shallow source, the focal depth being $4 \mathrm{~km}$ (Alptekin et al., 1985, after Altinok and Ersoy, 2000). Other authors, however, concluded that the faulting type was either pure strike-slip or strike-slip with thrust component (see review in Altinok and Ersoy, 2000).

\section{[24], 4 December 1970, Sochi (eastern Black Sea)}

\author{
coordinates: $43^{\circ} 42^{\prime} \mathrm{N}, 38^{\circ} 30^{\prime} \mathrm{E}$ \\ cause: ER \\ tsunami intensity: $1-2 / 2-3$ \\ reliability: 3
}

A moderate earthquake $(M=5.1)$ which occurred at 01:59 GMT caused a rapid sea level rise at 05:20 local time (LT), a maximum rise by $34 \mathrm{~cm}$ at 06:05 LT and a maximum fall of $45 \mathrm{~cm}$ at 06:10 LT near the town of Sochi (Dobrychenko et al., 1975; after Nikonov, 1997a). However, it is not clear if these observations were macroscopic or from tide-gauge records, which is likely the case. Tsunami intensity of $k=\mathrm{I}-\mathrm{II}$ was estimated by Nikonov (1997a). Yalciner et al. (2004), apparently based on the previous Russian sources reported "sea oscillations with heights of $80 \mathrm{~cm}$ and period of $5 \mathrm{~min}$." The data available are not sufficient to suggest a possible generation mechanism for the sea level changes.

\section{[25], 2 August 1990, southern coast of the Azov Sea}

coordinates: $45^{\circ} 38^{\prime} \mathrm{N}, 36^{\circ} 31^{\prime} \mathrm{E}$

cause: GS(?)

tsunami intensity: $2 / 3$

reliability: 3

A sudden, short-lived sea level rise of $40 \mathrm{~cm}$ was observed on the southern coast of the Sea of Azov (Nikonov, 1997a). A tsunami intensity of $k=$ II was estimated by Nikonov (1997a).

\section{[26], 7 May 2007, Bulgarian Black Sea coast}

\author{
coordinates: $43^{\circ} 06^{\prime} \mathrm{N}, 28^{\circ} 36^{\prime} \mathrm{E}$ \\ cause: GS(?) \\ tsunami intensity: 3-4/4-5 \\ reliability: 4
}

According to Ranguelov et al. (2008b), a tsunami-like sea disturbance of non-seismic origin was observed on 7 May 2007 on the Bulgarian Black Sea coast from north to south, that is at a distance of about $150 \mathrm{~km}$, but it was stronger to the north. The sea oscillations lasted for several hours. In most places, people were more impressed by the sea withdrawal than by the sea rise, which may be suggestive that sea retreat was more remarkable than sea level increase. Turbulence, strong water currents, mud waters and foam in some sites (e.g., in Balchik and Kavarna) were described. The chief period of the oscillations was between 4 and $8 \mathrm{~min}$. at most places. The maximum sea level rising and lowering were $+1.2 \mathrm{~m}$ and $-2.0 \mathrm{~m}$, respectively. The tsunami caused only slight damage to the affected areas. In Kavarna, a 25-30 ton tourist boat was rotated violently according to its captain and 
was damaged near the anchor holes and in some other places, including the rudder. Many small fishing boats were cast onto the beach in Kavarna and Balchik Marinas. Debris was deposited on the shore.

Several accounts of eyewitnesses as well as reports of local port authorities and three tide-gauge records were available, collected and analysed by the above authors who thought that the tsunami was produced either by a submarine landslide or by atmospheric pressure pulses. By exploring the former hypothesis and performing numerical modelling, Ranguelov et al. (2008b) found that submarine mass movements taking place within a certain delimited source area on the shelf margin offshore Varna may have generated tsunamis compatible with the observations. However, Vilibić et al. (2010) found an atmospheric disturbance traveling toward $30^{\circ}$ (NNE) with an amplitude of $2-3 \mathrm{hPa}$ and a propagation speed of about $16 \mathrm{~m} \mathrm{~s}^{-1}$, passing through a few tens of kilometers-wide pathway over the region affected by the tsunami. This disturbance occurred in the lower troposphere, but it was capped by instable convective cell that preserved gravity disturbance's coherence over a region at least $150 \mathrm{~km}$ long. They performed an ocean modeling study and showed that such a disturbance is capable of generating large tsunami waves and strong currents over the shallow regions, following the observations throughout the region where maximum sea level oscillations have been documented. Therefore, Vilibić et al. (2010) suggested that this event has a potential to be classified as a meteotsunami, the first of such kind in the Black Sea.

\section{Tsunami sources and recurrence}

From the 26 events analysed above, nearly all were observed within the basin of the Black Sea with the exception of three events which were described to have occurred in the Azov Sea. The majority of the Black Sea tsunamis were observed in the NE part of the basin and particularly in the coastal zones of the Crimean peninsula. It is not clear if the increased tsunami reporting in Crimea is due to purely geophysical conditions or to social factors, given that Crimea has attracted attention as a settlement place since historical times, thus favouring the reporting of natural phenomena. Other regions of relatively frequent tsunami production were offshore of the Bulgarian coast and offshore of the northern Anatolian coast. Of interest is the possible cause of tsunamilike disturbances in Odessus, Ukraine, due to distant, large intermediate-depth earthquakes occurring in the Vrancea seismic source in the Romanian subduction zone.

The most frequent cause of tsunami generation was seismic activity but cases of tsunamis triggered by landslides were also described. However, some events remain uncertain as to the tsunami cause. Oaie et al. (2006b), in an attempt to collect historical tsunami data for the Romanian Black Sea coast, put forward the hypothesis that some sea waves observed there from 1957 to 1995 might be considered as tsunamis. Since the data they published were quite uncertain to be included in the tsunami catalogue, we only reproduced them in Table A1 in the Appendix A with the purpose of initiating possible further research.

To approach the mean repeat time, $T$, of tsunami occurrence in the Black Sea, we considered only those assigned a high reliability score, that is 4 or 3 at minimum. In the time interval from 544/545 up to the present, only two reliable events of high intensity $K \geq 7$ were reported, which very roughly indicates that $T \approx 750$ years. Reliable tsunamis of moderate intensity $4 \leq K<7$ were more frequent, given that in the time interval from 1650 up to the present five events were reported, that is $T \approx 72$ years. However, in the Black Sea there is no evidence for tsunamis of very high intensity $(K \sim 10)$ such as the $365 \mathrm{AD}$ and 1303 ones associated with big earthquakes occurring along the Hellenic arc and trench (e.g. Papadopoulos et al., 2007, 2010). In addition, the frequency of the tsunami occurrence is certainly lower in the Black Sea than in other seismotectonic units of the Mediterranean Sea, particularly in Greece and its adjacent seas as well as in South Italy. From this point of view, the tsunami hazard in the Black Sea is low to moderate. On the other hand, the historical and recent cases examined in this study imply that the tsunami hazard in the Black Sea is not negligible.

From the three events observed in the Azov Sea, two were attributed to earthquakes and one was triggered by an unknown cause. The tsunami hazard in the Azov Sea is very low because of the very low seismicity but also because of the shallow water prevailing there which does not favour tsunami generation.

\section{Conclusions and discussion}

Data on tsunamis occurring in the Black Sea and the Azov Sea from the 1st century BC up to the present were updated and critically evaluated on the basis of geological, archaeological, historical and instrumental data. The data and the evaluation results were compiled in the standard format developed for the New European Tsunami Catalogue by a large group of scientists involved in several EUfunded research projects since the 90's. Twenty nine events were examined but three of them, supposedly occurring in $557 \mathrm{AD}, 815 \mathrm{AD}$ and 1341 or 1343 , very likely were falsely reported. The 557 one was just a duplication of the 544/545 earthquake and tsunami key event (see Introduction) which had its source offshore of the Bulgarian Black Sea coast. As for the 815 event, an earthquake was documented near Constantinopole but no tsunami was reported. The 1341 or 1343 earthquake which supposedly caused a tsunami in Crimea was just a missinterpretation of the 1343 earthquake and tsunami event which hit Constantinopole in the Marmara Sea but did not affected the Black Sea. 
The geographical distribution of the tsunami sources in the Black Sea was discussed by several authors (e.g. Solov'eva et al., 2004; Yalciner et al., 2004). We can conclude from the revised tsunami catalogue presented in this paper that the majority of the 26 events examined were reported from the coastal zones of Crimea. Other regions of relatively frequent tsunami production were offshore of the Bulgarian coast and offshore of the northern Anatolian coast, while tsunami-like disturbances caused by large intermediate-depth earthquakes occurring in Vrancea, Romania, were reported in Odessus, Ukraine. For each of the 26 events examined, a reliability score was assigned for being real tsunami waves. In a 4grade scale, 22 events were classified as reliable ones getting a score of 3 or 4 . Most of them were caused by earthquakes, such as the key tsunami event of 544/545, but a few were attributed either to aseismic earth slumps or to unknown causes.

The tsunami intensity was also estimated on both the traditional 6-grade scale and on the new 12-grade scale introduced by Papadopoulos and Imamura (2001). From $544 / 545$ up to now, only two reliable events of high intensity $K \geq 7$ have been reported, which very roughly indicates that the mean repeat time is around 750 years. Five reliable tsunamis of moderate intensity $4 \leq K<7$ were observed from 1650 up to the present, which implies a recurrence of 72 years as an average. The earthquake magnitude $(M)$ frequency $(N)$ relationship, which is historically known as G-R (Gutenberg and Richter, 1944) and describes the earthquake magnitude distribution by the formula

$\log N=a-b \cdot M$

where $a$ and $b$ are parameters, was applied to describe also the tsunami intensity distribution by replacing $M$ by $K$ in the formula (1) (e.g. Papadopoulos, 2003). Then, considering that theoretically $b=1$, the repeat time of events increases by a factor of 10 with the increase of the size of events by one order of magnitude or intensity. This implies that the repeat times of Black Sea tsunamis found above from rough calculations due to the very small statistical samples of the tsunami events are consistent with theoretical expectations. However, in the Black Sea there is no evidence for tsunamis of very high intensity $(K \sim 10)$ such as the $365 \mathrm{AD}, 1303$ and 1956 ones associated with big earthquakes occurring along the Hellenic arc and trench, Greece, or the 1908 one in the Messina strait, Italy. This observation along with the relatively low frequency of tsunami indicates that the tsunami hazard in the Black Sea is low to moderate but not negligible.

The tsunami hazard in the Azov Sea is very low because of the very low seismicity but also because of the shallow water prevailing there. In fact, only three possible events were reported.

\section{Appendix A}

\section{Events not included in the present catalogue}

\section{A1 557 AD}

These are an earthquake and tsunami events which are listed by Nikonov (1997a) under date "557 AD, 15 or 16 August, possibly $555 \mathrm{AD}$ ". The description says that "Bulgarian coast south of the town of Burgas, Bosporus. Sea flooded the shore inland through $4.5 \mathrm{~km}$ ". The only documentary source used is a Russian edition about the Byzantine chronicographer Cedrenus. Several Byzantine and other authors reported on a very strong earthquake which damaged Constantinopole on 14 December 557 but no tsunami was reported (e.g. Guidoboni et al., 1994; Ambraseys, 2009). In addition, an earthquake was reported by Cedrenus $(674-675,736)$ in July 555 without specifying location. Again no tsunami was mentioned. Therefore, the event listed by Nikonov (1997a) is judged to be falsely reported. A possible explanation for this is that Cedrenus (657) also wrote about the event of 544/545, see event [4], and that an amalgamation of the two accounts of Cedrenus concluded with the false report. On the authority of Nikonov (1997a) the 557 false event was also listed in the Black Sea tsunamis by Yalciner et al. (2004).

\section{A2 815 AD}

Christoskov and Typkova-Zaymova (1979) reported on a passage from St. Nikiforus life which says that in 814 or 815 unusual events were observed, such as earthquakes and trembles, and that the sea instead of food produced storms and chaos. Christoskov and TypkovaZaymova (1979) noted that this description is not very clear about tsunami effects and that likely does not indicate the earthquake of $815( \pm 1)$ which possibly had its epicenter on land to the east of Adrianopole. Apparently those authors reported on St. Nikiforus, who was born in 758, became Bishop of Constantinpole in 806 and died in 822 . That strong earthquakes occurred between 813 and 820 in the Byzantine area but in unknown locations, results from a passage of the Byzantine historian (9th century) Georgius Monachus (Guidoboni et al., 1994). However, Ambraseys (2009) suggested that the earthquakes occurred in August 815 near Constantinpole. In any case, no tsunami was reported.

\section{A3 18 October 1343, Marmara Sea}

Nikonov (1997a) and subsequent authors listed an earthquake and tsunami event occurring in the Black Sea either in 1341 or in 1343 . The analysis that follows concluded that the event occurred in the Marmara Sea and that the Black Sea one was falsely reported. On 18 October 
Table A1. Elements of sea wave cases observed on the Romanian Black Sea coast from 1957 to 1995 . Data were collected by Oaie et al. (2006b) who put forward the hypothesis that some of the cases might be considered tsunamis. However, the data available are quite uncertain. For example, in all the cases listed there is a lack of data about the seismic activity as well as about parameters such as wave period and runup distance. Therefore, the cases are listed here with the purpose of initiating possible further research.

\begin{tabular}{lllll}
\hline Year & Month & Type of observation & Zone & Effects \\
\hline 1957 & & Instrumental & South, south jetty & $\begin{array}{l}\text { 8.66 m (?) high waves to the entrance in the Sulina canal } \\
\text { from south to north }\end{array}$ \\
1958 & May & Visual & Sulina canal & $\begin{array}{l}\text { Floods on jetties situated along the Sulina canal and } \\
\text { in the eastern part of the town }\end{array}$ \\
1960 & December & Visual & $\begin{array}{l}\text { Sulina canal and } \\
\text { harbour }\end{array}$ & $\begin{array}{l}\text { Complete flooding of the canal jetties and } \\
\text { of the meteorological station platform; displacements } \\
\text { of rock blocks that are fixing the jetties; sudden and } \\
\text { violent displacement of ships located within the harbour }\end{array}$ \\
1993 & August & $\begin{array}{l}\text { Instrumental } \\
\text { Visual }\end{array}$ & $\begin{array}{l}\text { Sulina canal } \\
\text { Sahalin Island }\end{array}$ & $\begin{array}{l}\text { Floods on the Sulina canal jetties } \\
\text { Total flooding of the island }\end{array}$ \\
1995 & May & Visual & Sulina canal & Floods on the Sulina canal jetties and of the nearby beach \\
\hline
\end{tabular}

1343, two strong earthquakes hit Constantinopole and other places of NW Turkey, the second one completing the damage caused by the first one few hours earlier. The second earthquake was associated with a tsunami which caused damage to the coastal zone of Constantinopole and possibly along the Thracian coast. Documentary sources for both the earthquakes and the tsunami were reviewed extensively by Evagelatou-Notara (1993), Guidoboni and Comastri (2005) and Ambraseys (2009). In the tsunami catalogues of Ambraseys (1962), Antonopoulos (1973), Papadopoulos and Chalkis (1984), Altinok and Ersoy (2000), Papadopoulos (2001) the event was also placed in the Marmara Sea. There is no evidence for tsunami observed in the Black Sea.

Nikonov (1997a), in his list of Black Sea tsunamis included one which supposedly occurred on the western Crimean coast in 1341 or 1343 and caused the sea to ran by $10 \mathrm{~km}$ beyond the shoreline near the town of Evpatoria. Strangely enough he placed the earthquake epicenter inland from the SE Bulgarian Black Sea coast at $41.5^{\circ} \mathrm{N}-28.0^{\circ} \mathrm{E}$ $( \pm 0.5)$. To explain the large distance of about $500 \mathrm{~km}$ between the earthquake epicenter and western Crimean coast, Nikonov (1997a) suggested that although no landslidetriggered tsunamis by teleseismic inland earthquakes were reported in the Black Sea, "they can be assumed for the East Anatolia earthquake of 1939 and the 1341 Thracia event". However, the only historical document cited by Nikonov (1997a) was that of Cantacuzenos (ii, 477-478 and iii, 29) who reigned in Constantinopole 1341-1347. This document, however, is clearly referring to the 18 October 1343 Constantinopole earthquakes. Very possibly the key for the misunderstanding of Nikonov (1997a) was the earthquake catalogue of Smirnov (1931) who placed the earthquake in Cherson, Crimea. On the authority of Nikonov (1997a), that event was also listed in the Black Sea tsunamis by Pelinovsky (1999) and Yalciner et al. (2004).

Acknowledgements. This paper is part of the EU research project SCHEMA, contract number 030963, 6th Framework Programme. We are thankful to two reviewers as well as to the Guest Editor Ira Didenkulova for their productive comments and corrections which have improved this paper.

Edited by: I. Didenkulova

Reviewed by: E. Pelinovsky and another anonymous referee

\section{References}

Alptekin, Ö., Nabalek, J. L., and Toksöz, N.: 3 Eylül 1968 Bartin Depreminin kaynak mekanizmasive Karadeniz'in aktif tektonigi hakkinda düşünceler, Deprem Arastirma Bülteni, 50, 5-28, 1985 (in Turkish).

Altinok, Y.: Tsunamis along the coast of the Black Sea, in: Proceedings of the Second Balkan Geophysical Congress and Exhibition, 46-47, 1995.

Altinok, Y. and Ersoy, S.: Tsunamis Observed on and Near the Turkish Coast, Nat. Hazards, 21, 185-205, 2000.

Ambraseys, N. N.: Data for the investigation of the seismic seawaves in the Eastern Mediterranean, B. Seismol. Soc. Am., 52, 895-913, 1962.

Ambraseys, N. N.: Earthquakes in the Mediterranean and Middle East - A multidisciplinary study of seismicity up to 1900, Cambridge University Press, UK, 947 pp., 2009.

Ambraseys, N. N. and Finkel, C. F.: The Seismicity of Turkey and Adjacent Areas, A Historical Review, 1500-1800, EREN Ltd, Istanbul, 240 pp., 1995. 
Antonopoulos, J.: Tsunamis tis Anatolikis Mesogeiou apo tis Archaeotitos mexri simeron (Tsunamis of the East Mediterranean from the Antiquity to Present Times), Athens, 168 pp., 1973 (in Greek).

Antonopoulos, J.: Catalogue of tsunamis in the eastern Mediterranean from antiquity to present times, Ann. Geofis., 32, 113130, 1979.

Bernaerts, A.: Turkey earthquake - 27 December 1939, in: Climate Change and Naval War - A Scientific Assessment, Trafford, Canada/UK, 141-148, 2005.

Christoskov, L. and Typkova-Zaymova, B.: The possible tsunamigenic characteristics of earthquake sources in our Black Sea Coast, Bulgarian Geophysical Journal (BGJ), 5, 98-99, 1979 (in Bulgarian).

Christoskov, L., Gergova, D., Iliev, I., and Rizzo, V.: Traces of seismic effects on archaeological sites in Bulgaria, Ann. Geofis., 38, 5-6, 1995.

Choi, B. H., Lee, H. J., Imamura, F., and Shuto, N.: Computer animation of marine process - tsunami events, Journal of the Korean Society of Coastal and Engineers, 5, 19-24, 1993.

Constantinescu, L. and Marza, V.: Long-term strong seismicity of Vrancea (Romania) region, in: Proceedings of the 21st ESC General Assembly, 23-27 August 1988, Sofia, Bulgaria, 58-66, 1989.

Dvoichenko, P. A.: Earthquakes in the Crimea, Krasnyi Krym, 218, 1927 (in Russian).

Dvoichenko, P. A.: The Black Sea Earthquakes of 1927 in the Crimea, in Chernomorskie zemletryaseniya 1927 i sud' by Kryma (The Black Sea Earthquakes of 1927 and the Destiny of the Crimea), Krymgosizdat, Simferopol, 77-98, 1928 (in Russian).

Dobrychenko, A. V., Zaraiskii, M. P., Vandysheva, N. V., and Shebalin, N. V.: The Sochi Earthquake Swarm of 1969-1971, in Zemletryaseniya V SSSR v $1971 \mathrm{~g}$ (Earthquakes in the Soviet Union in 1971), Nauka, Moscow, 36-45, 1975.

Dotsenko, S. F.: Calculation of the travel times of long waves in the Black Sea by the ray method, Morsk. Gidrof: Zh., 2, 39-43, 1993.

Dotsenko, S. F.: The Black Sea tsunamis, Izvestiya Atmospheric and Oceanic Physics, 30(4), 483-489, 1995.

Dotsenko, S. F. and Eremeev, V. N.: Analysis of the necessity and possibility of tsunami early warning on the Black sea coast, Phys. Oceanogr., 18, 288-296, 2008.

Dotsenko, S. F., and Ingerov, A. V.: Characteristics of tsunami waves in the Black Sea according to the data of measurements, Physical Oceanography, 17, 17-28, 2007a.

Dotsenko, S. F. and Ingerov, A. V.: Spectra of the Black-Sea tsunamis, J. Phys. Oceanogr., 17, 269-277, 2007 b.

Dotsenko, S. F. and Konovalov, A. V.: Tsunami waves in the Black Sea in 1927: observations and numerical modelling, J. Phys. Oceanography, 7, 389-401, 1996.

Engel, M.: Hydrodynamical - numerical investigations of motions in the Black Sea, Mitleilungen des Instituts für Meersktrnde der Universität Hamburg, Germany, 22 pp., 1974.

Evagelatou-Notara, F.: . . . Kai ta polla tis Peloponnisou ... seismou gegonasi paranaloma (... And everything in Peloponnisos ... became a prey to the flames because of earthquakes), in: Proc. of the 3rd Conf. Peloponnisian Studies, Kalamata, 8-15 September 1985, 427-448, 1987-1988 (in Greek with English Summary).
Evagelatou-Notara, F.: Seismoi sto Vyzantio apo ton 13o mexri ton 15o aiona - Istoriki exetasi (Earthquakes in Byzantium from 13th to 15 th century - A historical examination), Parousia, Athens, 24, 1-179, 1993 (in Greek with English Summary).

Fomicheva, L., Rabinovich, A., and Demidov, A.: Tsunamis in the Black Sea. In: Hydrometeorology and Chemistry of the USSR Seas, Gidrometeoisdat, St. Petersburg, 4, 352-354, 1991 (in Russian).

Georgiades, A.: Peri seismon kai antiseismikon oikodomimaton (About earthquakes and antiseismic buildings), Athens, 306 pp., 1904 (in Greek).

Gergova, D., Iliev, I., and Rizzo, V.: Evidence of a seismic event on Thracian tombs dated to the Hellenistic period (Sveshtari, Northeastern Bulgaria), Ann. Geofis., 38, 5-6, 1995.

Grigorash, Z. K.: The Black Sea tsunami of 1927 by mareograph recording, Trans. Marine Hydrophys. Instit., 17, 59-67, 1959a (in Russian).

Grigorash, Z. K.: Propagation of tsunamis in the Black Sea in 1927, Trans. Marine Hydrophys. Instit., 18, 113-116, 1959b (in Russian).

Grigorash, Z. K.: A review of distant mareograms of some tsunamis in the Black Sea, Trans. Sakhalrn Compex Sci. Rex Ins., 29, 271278, 1972.

Grigorash, Z. K. and Korneva, L. A.: Tsunamis in the Black Sea, in: "International Tsunami Information Center, Newsletter" Honolulu, Hawaii, 2, 2, 1969.

Grigorash, Z. K. and Korneva, L. A.: New data about the Black Sea tsunami of December 26, 1939, in: International Tsunami Information Center, Newsletter Honolulu, Hawaii, 3, 3 pp., 1970.

Grigorash, Z. K. and Korneva, L. A.: Mareograph data about the Black Sea tsunami caused by the Turkish earthquake in December 1939, Oceanology, 12, 417-422, 1972a.

Grigorash, Z. K. and Korneva, L. A.: Wave field maps and tsunami energy in the Black Sea, Izvestiya Atmospheric and Oceanic Physics, 8, 562-566, 1972b (in Russian).

Grigorova, E. and Grigorov, B.: Earthquakes and seismic lines in Bulgaria, Bulgarian Academy of Sciences, Sofia, 83 pp., 1964 (in Bulgarian).

Guidoboni, E., Comastri, A., and Traina, G.: Catalogue of ancient earthquakes in the Mediterranean area up to the 10th century, Pub. Ist. Nazion. Geofisica, Rome, 1994.

Gutenberg, B. and Richter, Ch.: Frequency of earthquakes in California, B. Seismol. Soc. Am., 34, 185-188, 1944.

Iida, K.: Catalog of tsunamis in Japan and its Neighbouring Countries, Dept. of Civil Engin., Aichi Institute of Technology, Japan, 52 pp., 1984.

Ketin, I. and Abdüsselamoglu, S.: Bartin Depreminin etkileri, TJK Bülteni, 12(1-2), 66-77, 1969.

Korneva, L. A. and Grigorash, Z. K.: Observational characteristics of the energy spectra of Black Sea waves, Izvestiya Atmospheric and Oceanic Physics, 15, 63-67, 1979.

Kuran, U. and Yalciner, A. C.: Crack propagations, earthquakes and tsunamis in the vicinity of Anatolia, in: Tsunamis in the World, edited by: Tinti, S., Kluwer Acad. Publ., 159-175, 1993.

Lander, J. F.: Seismological notes - September and October 1968, B. Seismol. Soc. Am., 59, 1023-1030, 1969.

Litvinenko, G. I. and Strekalov, S. S.: Parameters and characteristics of Black Sea low-frequency waves of seismic origin, Hydrotechnical Construction, 35, 333-336, 2001. 
Mallet, R. and Mallet, J.: Catalogue of Recorded Earthquakes from 1606 BC to AD 1850, Brit. Assoc. Rep., London, 1852-1854, 1855.

Markevich, A. I.: A Chronicle of Crimean Earthquakes (A Historical Summary) in Chernomorskie zemletryaseniya 1927 i sud' by Kryma (The Black Sea Earthquakes of 1927 and the Destiny of the Crimea), Krymgosizdat, Simferopol, 63-73, 1928.

Milne, J.: Catalogue of Destructive Earthquakes, Rep. of the 18th Meeting of the British Association for the Advancement of Science - Portsmouth 1911, 31 August-7 September, London, 640-740, 1912.

Montandon: Les tremblements de terre destructeurs en Europe, Catalogue par territoirs seismique, de l'an 1000 à 1940, Geneve, 195 pp., 1953 (in French).

Nikonov, A. A.: Large Earthquakes and the Seismic Potential of the West Crimean (Sevastopol) Source Zone, Fiz. Zemli, 11, 20-31, 1994 (in Russian).

Nikonov, A. A.: Tsunamis occurrence on the coasts of the Black Sea and the Sea of Azov, Izvestiya, Physics of the Solid Earth, 33, 77-87, 1997a.

Nikonov, A. A.: Tsunami - a Threat from the South, Science in Russia, 6, 13-18, 1997b.

Oaie, Gh., Ioane, D., Diaconescu, M., Seghendi, A., Lazaroiu, Gh., and Ruzsa, Gy.: Cercetari multidisciplinare privind hazardele naturale. Studiu de caz: Producerea fenomenului tsunami in Marea Neagra, Acronim-PROFET, Hazard Natural: eventimente in Marea Neagra, 27-32, 2006a (in Romanian).

Oaie, Gh., Secrieru, D., Seghedi, A., Ioane, D., and Diaconescu, M.: Preliminary assessment of the tsunami hazard for the Romanian Black Sea area: historical and paleotsunami data, Geosciences, 300-302, 2006b.

Papadopoulos, G. A.: Tsunami Hazard in the Eastern Mediterranean: strong earthquakes and tsunamis in the Corinth Gulf, Central Greece, Nat. Hazards, 29, 437-464, 2003.

Papadopoulos, G. A. and Chalkis, B.: Tsunamis observed in Greece and the surrounding area from antiquity up to the present times, Mar. Geol., 56, 309-317, 1984.

Papadopoulos, G. A. and Imamura, F.: A proposal for a new tsunami intensity scale, in: Proceedings International Tsunami Symposium 2001, Seattle, Session 5(5-1), 569-577, 2001.

Papadopoulos, G. A. and Kortekaas, S.: Characteristics of landslide generated tsunamis from observational data, in: Submarine Mass Movements and their Consequences, edited by: Locat, J. and Mienert, J., Kluwer Acad. Publ., 367-374, 2003.

Papadopoulos, G. A. and Lefkopoulos, G.: Magnitude-distance relations for liquefaction in soil from earthquakes, B. Seismol. Soc. Am., 83, 925-938, 1993.

Papadopoulos, G. A. and Plessa, A.: Magnitude-distance relations for earthquake-induced landslides in Greece, Eng. Geol., 58, 377-386, 2000.

Papadopoulos, G. A., Daskalaki, E., Fokaefs, A., and Giraleas, N.: Tsunami hazards in the Eastern Mediterranean: strong earthquakes and tsunamis in the East Hellenic Arc and Trench system, Nat. Hazards Earth Syst. Sci., 7, 57-64, doi:10.5194/nhess-7-57-2007, 2007.

Papadopoulos, G. A., Daskalaki, E., Fokaefs, A., and Giraleas, N.: Tsunami hazard in the Eastern Mediterranean sea: strong earthquakes and tsunamis in the west Hellenic arc and trench system, J. Earthq. Tsunami, 4(3), 145-179, 2010.
Papazachos, B. C. and Papazachou, C. B.: The Earthquakes of Greece, Ziti Editions, Thessaloniki, 286 pp., 2003 (in Greek).

Parejas, I., Akyol, M., and Altinli, E.: Le tremblement de terre d'Erzincan du 27 Decembre 1939 (secteur occidental), I.Ü. Jeoloji Enstitüsü Neşriyati, 10, 187-222, 1942 (in French).

Pelinovsky, E.: Preliminary estimates of tsunami danger for the northern part of the Black Sea, Phys. Chem. Earth Pt. A, 24, 175-178, 1999.

Perissoratis, C. and Papadopoulos, G. A.: Sediment instability and slumping in the southern Aegean Sea and the case history of the 1956 tsunami, Mar. Geol., 161, 287-305, 1999.

Ranguelov, B.: Seismicity and tsunamis in the Black Sea, in: Proc. of the 25th ESC General Assembly, September 9-14, Reykjavik, Iceland, 667-673, 1996.

Ranguelov, B.: Possible tsunami deposits discovered on the Bulgarian Black Sea coast and some applications, in: Submarine Landslides and Tsunamis, edited by: Yalçiner, A. C., Pelinovski, E., Synolakis, C. E., and Okal, E., Kluwer, 237-242, 2003.

Ranguelov, B., Spassov, E., and Dotsev, N.: A model of tsunami generation from Bulgarian earthquake sources in the Black Sea area and prediction of their possible effects, BGJ, 9, 91-99, 1983.

Ranguelov, B., Spassov, E., and Dotsev, N.: Tsunami danger for the Bulgarian Black Sea coast, BGJ, 2, 6-73, 1985.

Ranguelov, B., Spassov, E., Dotsev, N., and Pavlov, I.: Spectra of tsunami in the Black Sea, BGJ, 13, 3-58, 1987.

Ranguelov, B., Mircheva, E., Lazarenko, I., and Encheva, R.: The archaeological site-possible evidence about multihazard ancient events, in: Proc. Conf. Geoarchaeology and Archaelomineralogy, 2008 Sofia, Publishing House "St. Ivan Rilski”, Sofia, 347352, 29-30 October 2008a.

Ranguelov, B., Tinti, S., Pagnoni, G., Tonini, R., Zaniboni, F., and Armigliato, A: The nonseismic tsunami observed in the Bulgaria Sea on 7 May 2007 - Was it due to a submarine landslide?, Geophys. Res. Lett., 35, L18613, doi:10.1029/2008GL034905, 2008b.

Richter, C. F.: Elementary Seismology, Eurasia Publ. House (Pvt.) Ltd., New Delhi, 1956.

Schuiling, R. D., Cathcart, R. B., Badescu, V., Isvoranu, D., and Pelinovsky, E.: Asteroid impact in the Black Sea. Death by drowning or asphyxiation?, Nat. Hazards, 40, 327-338, 2007.

Selezov, I. and Ostroverkh, B.: Modelling of under-water seismic centres and the generation and transformation of tsunami waves in seismic areas, J. Phys. Oceanogr., 8, 57-68, 1997.

Shebalin, N. V., Karnik, V., and Hadzievski, D. (Eds): Catalogue of earthquakes. Part II: prior to 1901, UNDP/UNESCO Survey of the seismicity of the Balkan region, Skopje, 69 pp., 1974.

Smirnov, M. V.: Katalog zemletryasenii v Krymu (A catalogue of Crimean earthquakes), Simferopol, 1931.

Solov'eva, O. N. and Kuzin, I. P.: Seismicity and Tsunamis in the Northeastern Part of the Black Sea, Oceanology-USSR, 45(6), 781-794, 2005.

Solov'eva, O. N., Dotsenko, S. F., Kuzin, I. P., and Levin, B. V.: Tsunami in the Black Sea: Historical Events, Seismic sources, and Features of Propagation, Oceanology-USSR, 44(5), 638643, 2004.

Spassov, E. and Ranguelov, B.: Tsunami Danger in the Black Sea- Summary, in: Proceedings of the International Tsunami Symposium, International Union of Geodesy and Geophysics, 18-19 August 1987, NOAA/Pacific Marine Evironmental 
Laboratory, Washington, USA, 64-70, 1987.

Tappin, D. R., Matsumoto, T., Watts, P., Satake, K., McMurty, G. M., Matsuyama, M., Lafoy, Y., Tsuji, Y., Kanamatsu, T., Lus, W., Iwabuchi, Y., Yeh, H., Matsumotu, Y., Nakamura, M., Mahoi, M., Hill, P., Crook, K., Anton, L., and Walsh, J. P.: Sediment slump likely caused 1998 Papua New Guinea tsunami, EOS T. Am. Geophys. Un., 80(30), 329, 334, 340, 1999.

Tinti, S. and Maramai, A.: Catalogue of tsunamis generated in Italy and in Cote d'Azur, France: a step towards a unified catalogue of tsunamis in Europe, Ann. Geofis., 39, 1253-1299, 1996.

Vilibić, I., Šepić, J., Ranguelov, B., Mahović, N. S., and Tinti, S.: Possible atmospheric origin of the 7 May 2007 western Black Sea shelf tsunami event, J. Geophys. Res., 115, C07006, 12 pp, doi:10.1029/2009JC005904, 2010.

von Hoff, K. E. A.: Geschichte der Natürlichen Veränderungen der Erdoberfläche, Chronik der Erdbeben und Vulcan-Ausbrüche, edited by: Gotha Perthes, J., 5, 406 pp., 1841 (in German).

Wedding, H.: 3 Eylül 1968 de vukua gelen Bartin-Amasra Yersarsintisi, MTA Dergisi, 71, 135-141, 1968 (in Turkish).

Yalciner, A. and Pelinovsky, E.: The source mechanism of 1939 Black Sea Tsunami, AGU, Spring Meeting 2004, abstract \#OS13 A-06, 2004.
Yalciner, A., Pelinovsky, E., Talipova, T., Kurkin, A., Kozelkov, A., and Zaitsev, A.: Tsunamis in the Black Sea: Comparison of the historical, instrumental, and numerical data, J. Geophys. Res., 109, C12023, doi:10.1029/2003JC002113, 2004.

Zaitsev, A. I., Kozelkov, A. C., Kurkin, A. A., Pelinovsky, E. N., Talipova, T. G., and Yalciner, A. C.: Tsunami modeling in the Black Sea, Izvestia, Russian Academy of Engineering Sciences, Series: Applied Mathematics and Mechanics, 3, 27-45, 2002 (in Russian).

\section{Classical and Byzantine sources}

Cantacuzenos, Ioannis: Historiae, 3 volumes, 1828-1832, Corpus Scriptorum Historiae Byzantini, Bonn, 1828-1897.

Cedrenus: Synopsis historiarum, edited by: Bekker, I., Bonn, book number 657, 1838-39.

Glykas: Annales, edited by: Migne, J.-P., Paris, book number 269, 1866.

Malalas: Chronographia, edited by: Dindorf, L., Bonn, book number 481, 1831.

Strabo: Geographica, edited by: Meineke, A., Leipzig, VII, book number 319, 1877.

Theophanes: Chronographia, edited by: De Boor, C., Leipzig, book number 224, 1883-85 (repr. Hildesheim 1963). 